\title{
Nuove frontiere per la didattica del Disegno. Il futuro è nei comandi vocali?
}

\author{
Anna Osello \\ Francesco Alotto
}

Abstract

II disegno tecnico, considerato come strumento per operare nel campo della progettazione, della realizzazione, della gestione e della manutenzione di un manufatto edile, nel tempo si è evoluto nei metodi e negli strumenti di rappresentazione, mantenendo sempre un ruolo di linguaggio essenziale per la comunicazione tra i diversi professionisti coinvolti nel processo edilizio. Obiettivo di questo contributo è quello di indagare come la didattica del Disegno nel corso di Laurea in Ingegneria Edile, per prepararsi all'epoca della Società 5.0 (basata sulla co-operazione tra uomo e macchina), deve modificarsi tra teoria, tecnica e tecnologia, con approccio pluridisciplinare, integrando diversi saperi: il Disegno, la Matematica e l'Informatica. La metodologia proposta sperimenta i comandi vocali come interfaccia nell'utilizzo di software di disegno tecnico, ponendo sotto analisi il caso studio della creazione di figure coniche utilizzando input vocali, poiché la semplicità delle loro proprietà geometriche e l'eleganza delle loro applicazioni ingegneristiche, da sempre richiamano l'attenzione degli studiosi. I risultati raggiunti ovviamente rafforzano il forte legame tra la geometria descrittiva e l'algebra, poiché è noto che non esiste costrutto della geometria descrittiva che non possa essere tradotta analiticamente, e viceversa. Coniugando le teorie del Disegno, della Geometria analitica e i framework di intelligenza artificiale viene presentato un nuovo modus agendi per l'ingegnere del futuro.

Parole chiave

disegno tecnico, didattica, intelligenza artificiale, ingegneria edile, industria 5.0.

Nuove frontiere per la Didattica del Disegno Il futuro è nei comandi vocali?

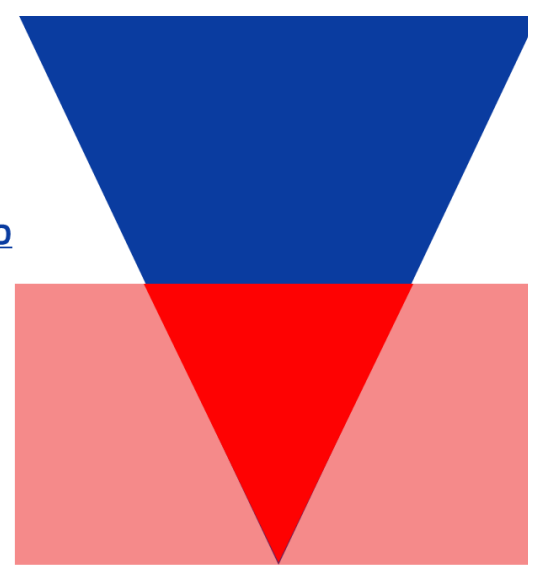




\section{Introduzione}

L'articolo esposto propone un colloquio ideale fra algoritmi che sembrerebbe non coinvolgere l'uomo, ma che in realtà proprio dall'uomo devono essere definiti in relazione alla conoscenza della teoria e alla padronanza delle tecniche e delle tecnologie. L'utilizzo dei comandi vocali come mezzo di interfaccia fra utilizzatore e il software di disegno tecnico poteva essere inteso, fino a una decina di anni fa, come utopico. Grazie alla maturazione tecnologica e alla diffusione in via open source di tool informatici che permettono lo sviluppo custom di tecnologie a interfaccia vocale, è stato possibile implementare un sistema di controllo vocale per l'interazione utente-software di disegno tecnico. Con i sistemi CAD che utilizzano una interfaccia tradizionale WIMP, cioè monitor, tastiera e mouse, la creazione e la modifica di modelli 3D è possibile solo mediante scomposizione in operazioni bidimensionali su sezioni o piani ausiliari, le quali, oltre a essere non intuitive e innaturali, ostacolano il flusso creativo e la rapida espressione e valutazione delle idee [Fiorentino 2002]. L'elemento essenziale che ha guidato il presente lavoro sono le diverse declinazioni che il disegno può assumere come (i) scienza della rappresentazione (linguaggio tecnico-scientifico), (ii) strumento di comunicazione (per la visualizzazione di uno spazio progettato), (iii) disciplina empirica (legata alla pratica costruttiva del cantiere), e come esso debba essere insegnato agli studenti di Ingegneria edile in un'epoca in continua e rapida evoluzione digitale e tecnologica (Industria 4.0). Gli elementi messi tra loro in correlazione sono diversi e sono di seguito descritti.

I) II punto di partenza deriva dalla necessità di garantire l'acquisizione con padronanza, da parte dello studente, della teoria che sta alla base della 'Geometria descrittiva', ossia della scienza che permette di rappresentare in modo inequivocabile su uno o più piani, oggetti bidimensionali e tridimensionali.

2) Inoltre, è necessario che vengano appresi gli elementi essenziali del 'Disegno tecnico' (2D e 3D), ossia dello 'strumento' che permette, attraverso un insieme di convenzioni, di fornire delle informazioni sulle funzioni, sulle forme, sulle dimensioni e sulle tecnologie relativi a un determinato manufatto e a ogni sua componente, assumendo il disegno come il principale mezzo di comunicazione che lo studente dovrà utilizzare non solo durante l'università, ma anche e soprattutto durante l'intera vita lavorativa.

3) Infine, è essenziale che lo studente impari a conoscere e padroneggiare gli 'strumenti' che volta per volta saranno ritenuti più idonei (anche in relazione alla continua e rapida evoluzione digitale) per la gestione dei dati, in relazione agli obiettivi prefissati. Deve trattarsi

Fig. I. Schema grafico dell evoluzione degli strumenti per il disegno tecnico in relazione alle diverse fasi delle rivoluzioni industriali. La linea tratteggiata in alto evidenzia come negli ultimi decenni l'andamento stia assumendo una tendenza esponenziale dopo secoli di trend lineare.

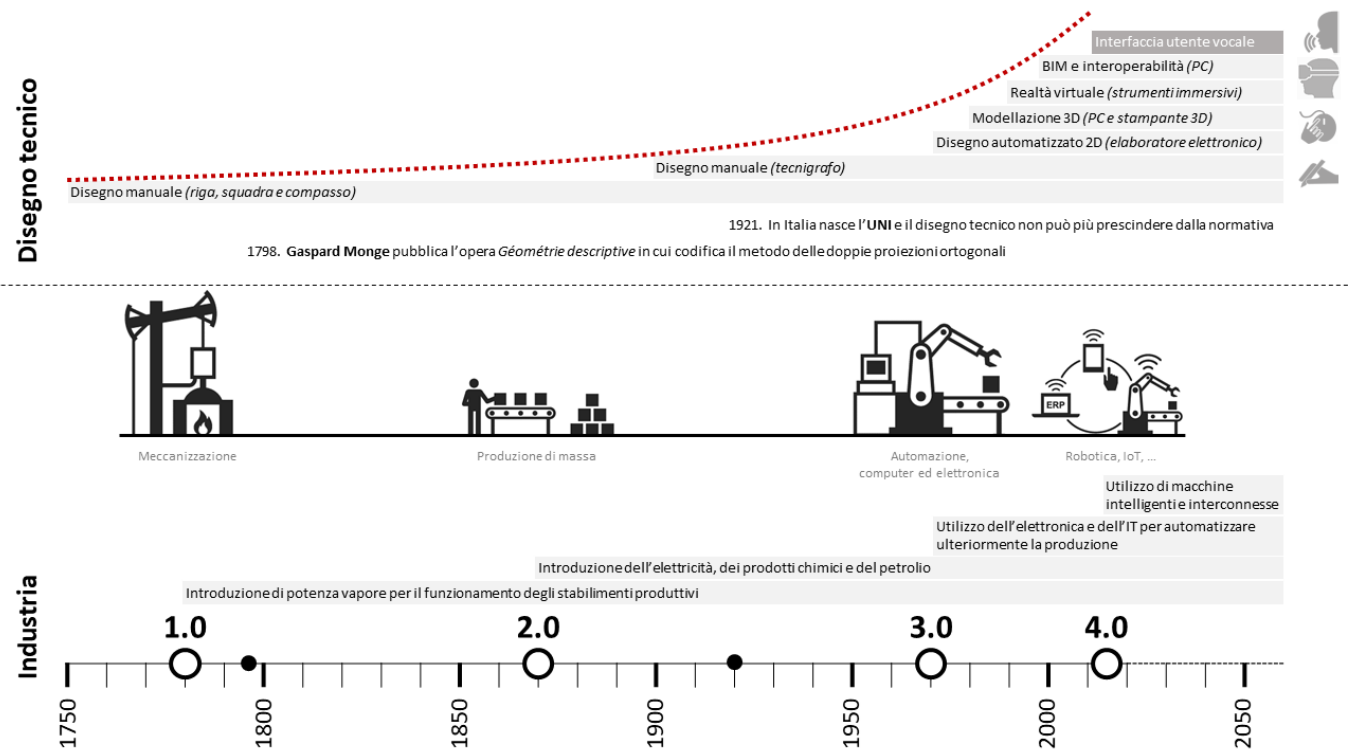


quindi di un apprendimento di tipo metodologico e comparativo, piuttosto che operativo su un singolo strumento. Da ciò si evince che il messaggio didattico deve essere inequivocabile: un aggiornamento continuo sarà sempre necessario, la cosa essenziale è apprendere un metodo di lavoro replicabile e che sfoci nell'integrazione dei saperi', imparando a lavorare con un approccio collaborativo e multidisciplinare.

\section{Metodologia}

Per meglio comprendere quanto appena descritto, è utile provare a schematizzare quanto è accaduto negli ultimi due secoli, correlando il mondo dell'industria con quello del Disegno tecnico. Ovviamente, come tutti gli schemi, quello proposto rappresenta una semplificazione di una realtà piuttosto complessa, pertanto, l'interazione tra gli strumenti e i metodi può variare nei tempi e nei luoghi (fig. I).

Partendo dal presupposto che nel tempo l'obiettivo rimane costantemente quello di dotarsi di disegni tecnici (e più recentemente anche di Database), capaci di fornire indicazioni sempre più efficaci per ogni fase del ciclo di vita di un manufatto (progettazione, realizzazione, gestione e manutenzione), dallo schema si evince chiaramente che: (i) da Gaspard Monge in poi (ossia dal 1798, anno di pubblicazione dell'opera Géométrie descriptive, a oggi), sono cambiati sia gli strumenti che i metodi; (ii) particolarmente interessanti risultano essere gli effetti dell'Industria 3.0 (la "rivoluzione informatica"), poiché cambiano drasticamente metodi e concezioni consolidati nel tempo. Proviamo a ripercorre in estrema sintesi ciò che è accaduto negli ultimi cinquanta anni. L'inizio dell'Industria 3.0 corrisponde a quello dell'automatizzazione del Disegno con il cosiddetto 'tecnigrafo elettronico'. Utilizzando software specifici di CAD 2D, il tracciamento delle linee, delle curve e dei raccordi, ma anche delle quotature, avviene attraverso la pressione di pulsanti e lo spostamento di cursori, rendendo in pochi anni obsoleti i mezzi precedenti (tecnigrafi), seppur nulla cambi nella impostazione dei disegni per quanto riguarda i metodi di rappresentazione (ciò che prima veniva disegnato sui fogli di carta, ora viene disegnato su file, utilizzando i layer). Successivamente, in considerazione del fatto che i punti non sono soltanto associati a un piano, ma possono essere collocati in uno spazio tridimensionale virtuale, definito dagli algoritmi del calcolatore, si sono aperti degli scenari completamente diversi con il CAD 3D che ha permesso lo sviluppo di una nuova declinazione del disegno al calcolatore. II modo con cui gli elementi vengono disegnati cambia drasticamente con il BIM: a modello del manufatto è possibile associare diverse proprietà. II Disegno tecnico diventa un Database dal quale si estraggono tutte le informazioni in forma grafica (proiezioni ortogonali, assonometrie e prospettive) e in forma alfanumerica; inoltre, le informazioni possono essere scambiate tra professionisti (interoperabilità). A integrazione di tutto quanto richiesto in termini di conoscenza, competenze e abilità per gestire gli strumenti e i metodi tipici dell'Industria 3.0, ora, con l'avvio dell'Industria 4.0, l'utilizzo di macchine intelligenti e interconnesse apre nuovi scenari (fig. 2).

Fig. 2. Schematizzazione concettuale dell'insegnamento del Disegno nell'epoca dell'Industria 4.0, dal sapere al saper fare, utilizzando volta per volta lo strumento più appropriato, sempre a partire da una solida conoscenza della geometria descrittiva e delle norme tecniche per il disegno.

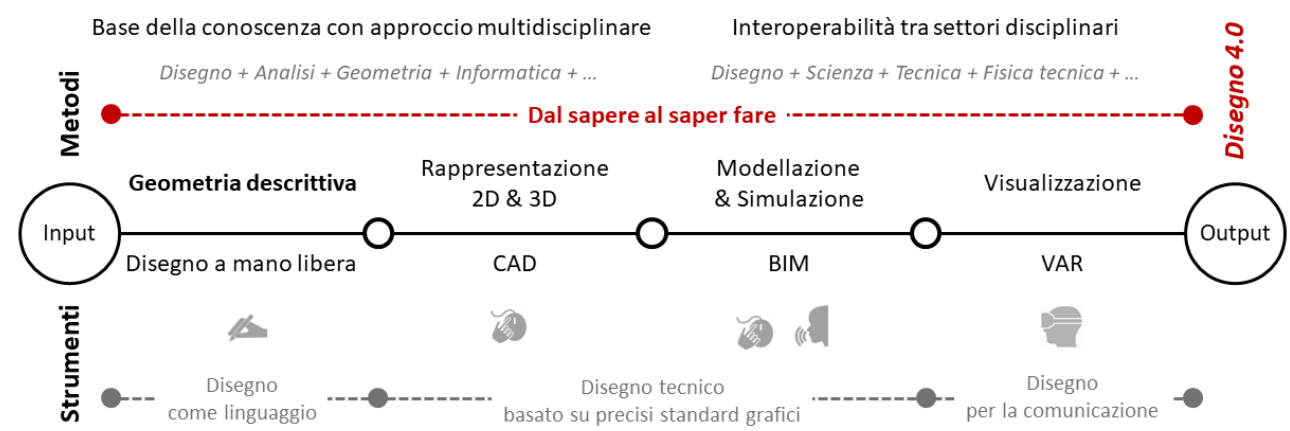


L'utilizzo dell'interfaccia utente vocale con il Disegno tecnico (BIM) dimostra che è richiesta una sempre maggiore integrazione di competenze pluridisciplinari (il Disegno, la Matematica e l'Informatica), la cui didattica nelle facoltà di Ingegneria Edile (ma non solo) deve essere in grado di dare una risposta immediata, per formare dei professionisti al passo con i tempi. Per questa ragione, al Politecnico di Torino è in fase di sperimentazione un modulo didattico da erogare al primo anno della Laurea che consenta agli studenti di imparare un approccio che mette insieme i quattro elementi precedentemente descritti (conoscenza della geometria descrittiva e degli elementi essenziali del disegno tecnico, padronanza degli strumenti, integrazione di saperi). L'approccio metodologico ha previsto una fase preliminare per la raccolta dei requisiti. La grande quantità di comandi presenti nell'interfaccia del software rende poco agevole l'utilizzo di metodi di interfaccia alternativi ai controlli manuali standard configurando, come principale difficoltà nell'utilizzo di tecnologie basate sul controllo vocale, il fatto che gli elementi di interfaccia grafica che caratterizzano i software di disegno tecnico vengono a mancare. Per tal motivo, risulta necessario creare un metodo sostituivo per il compimento delle operazioni disponibili. Le best practices per la creazione di software che integrano assistenti vocali, definiscono in senso operativo come le query macchina - utente debbano essere formulate [Alexa Skills Documentation 2020]. Risulta fondamentale seguire delle regole semantiche, al fine di assicurare semplicità nei quesiti formulati, includendo criteri di chiarezza (omissione di aggettivi e termini fuorvianti che potrebbero minare la comprensione della richiesta) per ottenere un modello di dialogo che possa tener conto del fatto che l'utente non ha dinnanzi a sé testo o icone, ma interagisce e riceve input tramite il suono. II tema applicativo di questo esercizio tecnico è ricaduto nell'eleganza rappresentativa delle figure coniche, poiché la semplicità delle loro proprietà geometriche e l'eleganza delle loro applicazioni ingegneristiche, da sempre richiamano l'attenzione degli studiosi. Una volta selezionato il tema applicativo, è iniziata la preliminare fase di ingegnerizzazione dei prompt vocali dell'assistente.

Come mostrato nella figura 3, l'utente interagisce con la piattaforma attraverso input vocali dialogando con il device. Quest'ultimo immagazzinerà le informazioni e le trasmetterà attraverso protocollo HTTP REST al Cloud Provider, il quale, grazie ad algoritmi di intelligenza artificiale basati sul Natural Language Processing, convertirà le informazioni in variabili di sistema. La scelta di eseguire il processing in sede separata, sfruttando il cloud provider, deriva dal fatto che:

I) Gli algoritmi basati su Reti Neurali richiedono alta potenza computazionale e potrebbero provocare un overload su carico della CPU locale.

2) Molti assistenti vocali si appoggiano a un ambiente Cloud perfettamente integrato con le API esposte, con metodi di trasmissione ottimizzati e minimizzazione della latenza.

3) I dati vengono gestiti direttamente dal Cloud Provider e grazie agli alti standard di sicurezza, i dati vocali vengono immagazzinati rispettando le direttive di privacy attualmente vigenti.

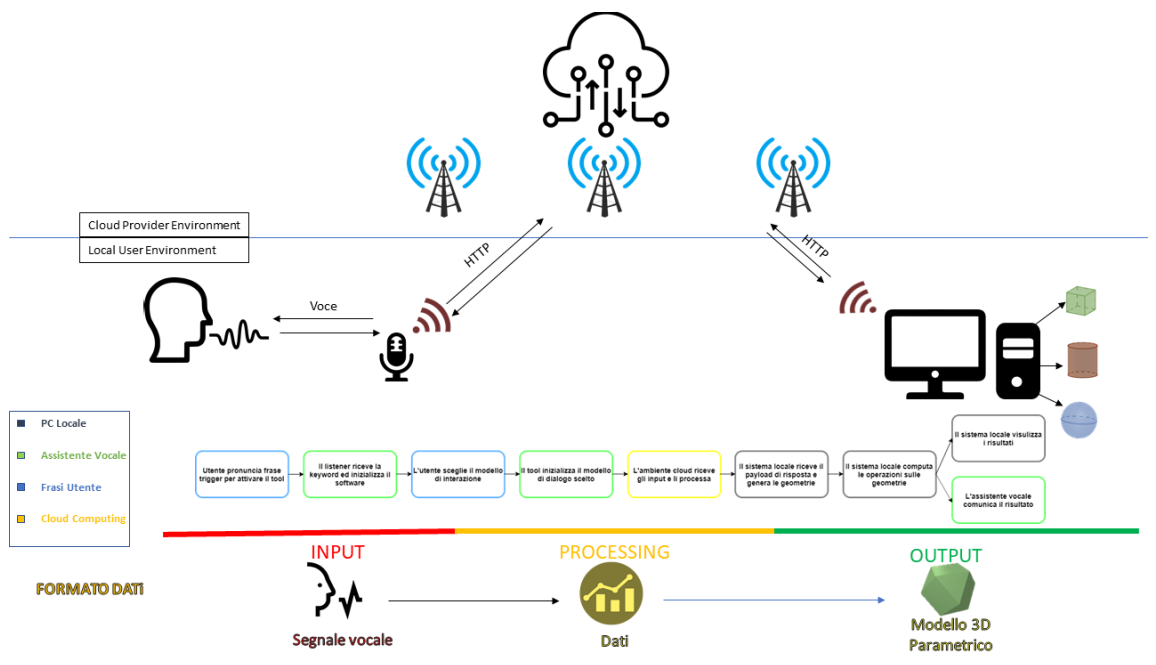


II processing prevede l'utilizzo dell'engine di Language Processing Amazon Alexa, che offre una suite di tool di sviluppo avanzati [Rao 20 I7]. Alla fine del processing su cloud verrà trasmesso al PC dell'utente un payload necessario alla creazione delle forme 3D in formato JSON, utilizzando anche in questo caso il protocollo di comunicazione HTTP. Una volta che il payload raggiunge il computer utente, grazie a una logica comprendente la schematizzazione dell'informazione in un file, di seguito denominato controller, vengono estratte le informazioni necessarie.

Le funzioni dello script sono:

I) Permettere la comunicazione real time tramite protocollo http.

2) Convertire e formattare il payload da formato JSON a formato csv.

Le informazioni presenti nel controller vengono trasferite nel software di modellazione utilizzando il plugin di programmazione visuale Dynamo. La conversione da JSON a csv risulta necessaria per compatibilità nella lettura delle informazioni near real time di Dynamo (fig. 4).

Fig. 4. Schematizzazione dello script di processing locale.

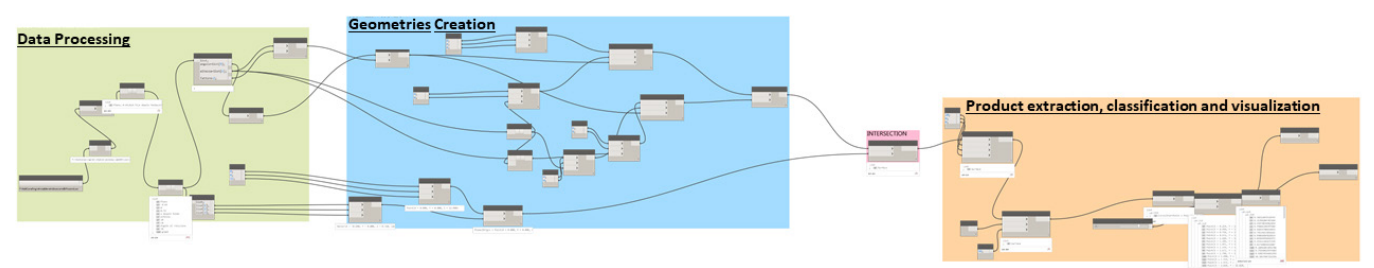

Durante la prima fase, il controller viene istanziato e le informazioni in esso contenute vengono contestualizzate, creando delle variabili all'interno del software di disegno tecnico. II sistema di raccolta dati all'interno dello script è dotato di funzioni di controllo che permettono, in caso di dato mancante o non correttamente formulato, il caricamento di valori di default definiti a priori. La seconda fase dell'algoritmo permette la creazione delle figure geometriche (cono a doppia falda/singolo e piano) partendo dai dati precedentemente caricati. Dopo aver creato i solidi, verrà utilizzata la logica di Dynamo per l'inserimento dei blocchi operazionali, necessari per svolgere l'interazione fra i solidi. Nel terzo blocco, il prodotto viene esportato in una posizione nota per la visualizzazione (fig. 5).

L'algoritmo si suddivide in due sotto algoritmi che si differenziano fra loro per numero di input accettati.

I) La procedura guidata prevede la ricezione di parametri riguardanti il cono e il piano. Le variabili includono il posizionamento del piano rispetto all'asse verticale in termini di coordinata spaziale e normale (inclinazione).

II) La procedura semplificata prevede la creazione del cono utilizzando le variabili di default precaricate all'interno dello script. L'utente comunicherà in tal caso l'inclinazione del piano rispetto a due assi. II posizionamento del piano lungo la coordinata verticale verrà inizializzato di default.

Il punto di congiunzione fra i due flussi è la classificazione e la visualizzazione del prodotto. In particolare, il software, risolvendo l'equazione generale delle coniche, estrae i parametri discriminativi per determinare la tipologia di figura ottenuta.

La procedura guidata presenta maggiore controllo a fronte di un'alta complessità computazionale e temporale rispetto alla procedura semplificata. Particolare focus è posto sul formato in cui tali variabili devono essere riportate (fig. 6). Qualora ci sia un errore (ad esempio la stringa ottenuta genera un errore quando convertita a numero), il sistema comunica che il valore non è stato correttamente processato e chiede all'utente di pronunciarlo nuovamente. Inoltre, seppur il dato sia corretto, per quanto riguarda i dati numerici, sono stati impostati degli intervalli di validità per evitare errori nel processing della geometria. Se il dato non dovesse superare il controllo, anche in questo caso, verrà nuovamente richiesto all'utente il valore segnalando l'anomalia. 

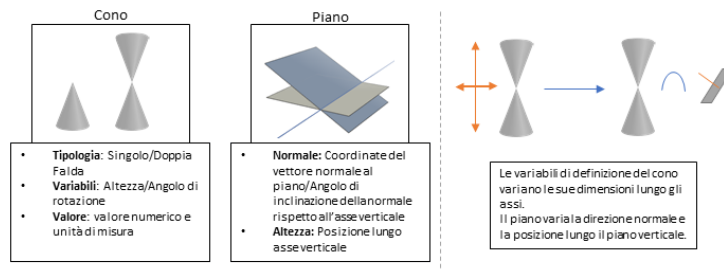

Procedura Guidata

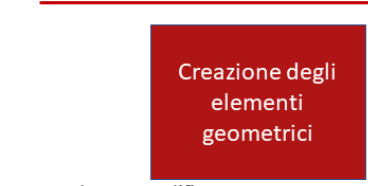

Procedura Semplificata

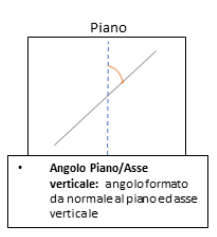

estrazione del

prodotto

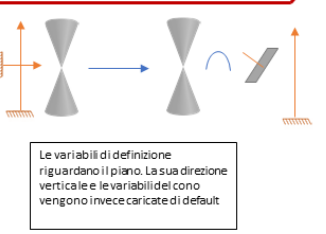

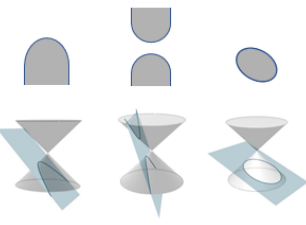

Classificazionee

visualizzazione

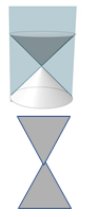

\section{Conclusioni}

L'algoritmo è stato valutato in termini di stabilità grazie al contributo di 10 tester che hanno provato il sistema out of box, senza assistenza da parte di personale formato e/o a conoscenza del Dialog Model. In particolare, i parametri di valutazione sono stati:

I) Efficacia dell'interazione e verifica del rispetto delle best practices.

2) Corretta trasmissione del flusso dati/corretta produzione del risultato.

Nel primo caso, grazie all'utilizzo di funzioni d'ausilio che vengono richiamate all'avvio del tool e su richiesta dell'utente, la totalità dei tester ha utilizzato con successo il tool, arrivando end to end al risultato finale. Nel secondo caso, con l'introduzione della logica di controllo sono stati risolti possibili errori semantici. II sistema ha mostrato ottimi risultati nell'utilizzo. II passaggio verso le interfacce vocali, che stanno sicuramente cambiando le esigenze dei fruitori (e non solo dei 'millennial'), se opportunamente sviluppate, potranno essere utilizzate sempre più in ambito ingegneristico per diventare anche strumenti di supporto per utenti con ridotte capacità di movimento degli arti e inabili nell'utilizzo delle interfacce classiche.

Fig. 6. Infografica in cui sono elencate le variabili, raggruppate per procedura, che l'utente scambia con il software.

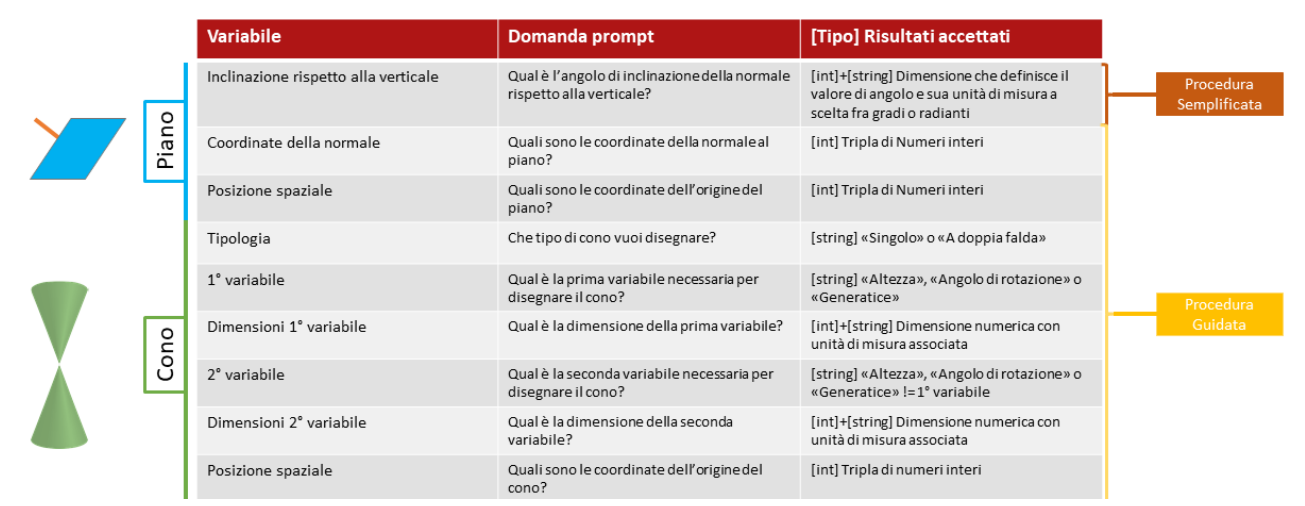




\section{Riferimenti bibliografici}

Alexa Skills Documentation (2020). Tratto da: Amazon Developers: <https://developeramazon.com/it-IT/docs/alexa/customskills/voice-design-best-practices-legacy.html>:

Fiorentino Michele, de Amicis Raffaele, Monno Giuseppe (2002). Nuove tecniche di interazione per il Design: il CADVirtuale. In DDD INTERFACCE, Rivista trimestrale Disegno e Design Digitale, vol. 7, pp. I - 14.

Migliari Riccardo (2003). Geometria dei modelli. Rappresentazione grafica e informatica per l'architettura e per il design. Bologna: Edizioni Kappa.

Migliari Riccardo (2009). Geometria descrittiva. Milano: CittàStudi.

Osello Anna, Bocconcino Maurizio Marco (20 l 0). Il disegno e l'ingegnere. Torino: Levrotto \& Bella.

Pascucci Cecilia (2000). Geometria descrittiva per il disegno industriale. Roma: Gangemi.

Rao Arun (2017). Comparing Amazon Alexa vs Google Home for Developers. Tratto da Medium: <https://medium.com/ voicelandia/comparing-amazon-alexa-vs-google-home-for-developers-cda37d9874c0>.

\section{Autori}

Anna Osello, Politecnico di Torino, anna.osello@polito.it

Francesco Alotto, Politecnico di Torino, francesco. alotto@polito.it

Per citare questo capitolo: Osello Anna, Alotto Francesco (2020). Nuove frontiere per la didattica del Disegno. II futuro è nei comandi vocali?/ New frontiers for the teaching of Technical Drawing. Is it possible to design with voice interfaces? In Arena A., Arena M., Brandolino R.G., Colistra D., Ginex G., Mediati D., Nucifora S., Raffa P. (a cura di). Connettere. Un disegno per annodare e tessere. Atti del $42^{\circ}$ Convegno Internazionale de Docenti delle Discipline della Rappresentazione/Connecting. Drawing for weaving relationships. Proceedings of the 42th International Conference of Representation Disciplines Teachers. Milano: FrancoAngeli, pp. 704-717. 


\title{
New Frontiers for the Teaching of Technical Drawing. Is it Possible to Design with Voice Interfaces?
}

\author{
Anna Osello \\ Francesco Alotto
}

Abstract

The technical drawing, considered as a tool to operate in the field of design, construction, management and maintenance of a building, has evolved over time in methods and tools of representation, always maintaining a role of essential language for communication between the various professionals involved in the building process. The aim of this contribution is to investigate how the didactics of Drawing in the Degree Course in Building Engineering, to prepare for the era of Society 5.0 (based on the co-operation between man and machine), must change between theory, technique and technology, with a multidisciplinary approach, integrating different knowledge: Drawing, Mathematics and Computer Science. The proposed methodology experiments with voice commands as an interface in the use of technical drawing software, putting under analysis the case study of the creation of conical figures using voice input, since the simplicity of their geometric properties and the elegance of their engineering applications have always attracted the attention of scientists. The results achieved obviously strengthen the strong link between descriptive geometry and algebra, since it is known that there is no construct of descriptive geometry that cannot be analytically translated, and vice versa. By combining the theories of Design, Analytical Geometry and Artificial Intelligence frameworks, a new modus agendi for the engineer of the future is presented.

Keywords

technical drawing, didactics, artificial intelligence, building engineering, industry 5.0.

New frontiers for the teaching of Technical Drawing

Design with voice interfaces

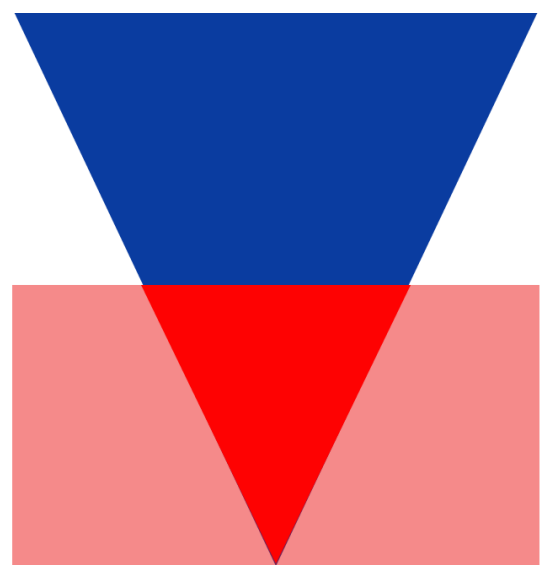


The article presented proposes an ideal conversation between algorithms which would seem not to involve man, but which must be defined by man himself in relation to knowledge of theory and mastery of techniques and technologies. The use of voice commands as a means of interface between the user and the technical drawing software could be understood, until about ten years ago, as utopian. Thanks to the technological maturation and the open source diffusion of computer tools that allow the custom development of voice interface technologies, it was possible to implement a voice control system for user-software interaction of technical design. With CAD systems that use a traditional WIMP interface, i.e. monitor, keyboard and mouse, the creation and modification of 3D models is possible only by breaking them down into two-dimensional operations on sections or auxiliary planes, which, besides being not intuitive and unnatural, hinder the creative flow and the rapid expression and evaluation of ideas [Fiorentino 2002].The essential element that has guided this work are the different declinations that drawing can assume as (i) science of representation (technical-scientific language), (ii) communication tool (for the visualization of a designed space), (iii) empirical discipline (related to the construction practice of the building site), and how it should be taught to students of Building Engineering in an era of continuous and rapid digital and technological evolution (Industry 4.0). The correlated elements are different and are described below.

I) The starting point derives from the need to ensure the student's mastery of the theory underlying Descriptive Geometry, i.e. the science that makes it possible to unequivocally represent two-dimensional and three-dimensional objects on one or more planes.

2) Furthermore, it is necessary to learn the essential elements of Technical Drawing (2D and $3 \mathrm{D}$ ), i.e. the tool that allows, through a set of conventions, to provide information on the functions, shapes, dimensions and technologies related to a given artefact and to each of its components, assuming drawing as the main means of communication that the student will have to use not only during the university, but also and above all during the whole working life.

3) Finally, it is essential that the student learns to know and master the tools that will be considered most suitable (also in relation to the continuous and rapid digital evolution) for data management, in relation to the set objectives. It must therefore be methodological and comparative learning, rather than operational learning on a single instrument. From this the didactic message must be unequivocal: continuous updating will always be necessary, the essential thing is to learn a replicable working method that leads to the integration of knowledge, learning to work with a collaborative and multidisciplinary approach.

Fig. I. Graphical diagram of the tools evolution for technical drawing in relation to the different phases of industrial revolutions. The dotted line at the top shows how in recent decades the trend has been assuming an exponential trend centuries of linear trend.

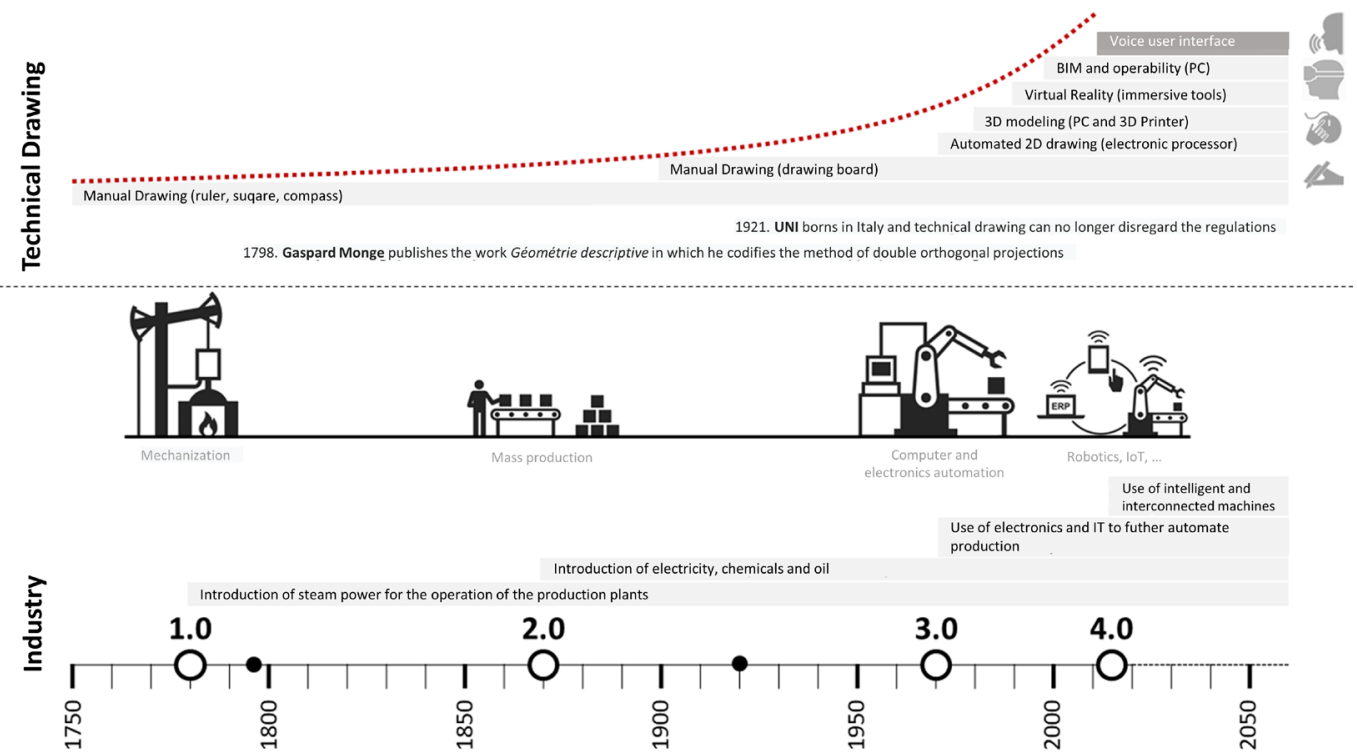




\section{Methodology}

To better understand what has just been described, it is useful to try to outline what has happened in the last two centuries, correlating the world of industry with that of Technical Drawing. Obviously, like all schemes, the one proposed represents a simplification of a rather complex reality, therefore, the interaction between tools and methods can vary in time and place (fig. I).

Starting from the assumption that over time the objective remains constantly to equip oneself with technical drawings (and more recently also with Databases), capable of providing increasingly effective indications for each phase of the life cycle of an artefact (design, construction, management and maintenance), it is clear from the diagram that: (i) from Gaspard Monge onwards (i.e. from 1798, the year of publication of the work Géométrie descriptive, to the present day), both tools and methods have changed; (ii) the effects of Industry 3.0 (the "computer revolution") are particularly interesting, as they drastically change methods and concepts consolidated over time. Let us try to retrace in extreme synthesis what has happened in the last fifty years. The beginning of Industry 3.0 corresponds to that of the automatization of Drawing with the so-called 'electronic technographer'. Using specific 2D CAD software, the tracing of lines, curves and fittings, but also of dimensions, takes place by pressing buttons and moving cursors, making the previous means (technographers) obsolete in a few years, even if nothing changes in the setting of the drawings with regard to the methods of representation (what was previously drawn on sheets of paper, is now drawn on file, using layers). Subsequently, in consideration of the fact that the points are not only associated to a plane, but can be placed in a virtual three-dimensional space, defined by the computer algorithms, completely different scenarios have been opened with 3D CAD which has allowed the development of a new declination of the drawing on the computer. The way the elements are drawn changes drastically with BIM: it is possible to associate different properties to the model of the object. The Technical Drawing becomes a Database from which all information is extracted in graphic form (orthogonal projections, axonometries and perspectives) and in alphanumeric form; moreover, information can be exchanged between professionals (interoperability). To integrate everything required in terms of knowledge, skills and abilities to manage the tools and methods typical of Industry 3.0, now, with the start of Industry 4.0, the use of intelligent and interconnected machines opens new scenarios (fig. 2).

The use of the vocal user interface with Technical Drawing (BIM) shows that an increasing integration of multidisciplinary skills (Drawing, Mathematics and Computer Science) is required, whose teaching in the faculties of Building Engineering (but not only) must be able to give an immediate response, to train professionals in step with the times. For this reason, the Polytechnic of Turin is experimenting a teaching module to be delivered in the first year of the Degree that allows students to learn an approach that combines the four elements previously described (knowledge of Descriptive Geometry and the essential ele-

Fig. 2. Conceptual schematization of the era of Industry 4.0, from knowledge to know from usow the to know-how, using the most appropriafrom a solid knowledge from a solid knowledge of descriptive geometry and technical standards for drawing.

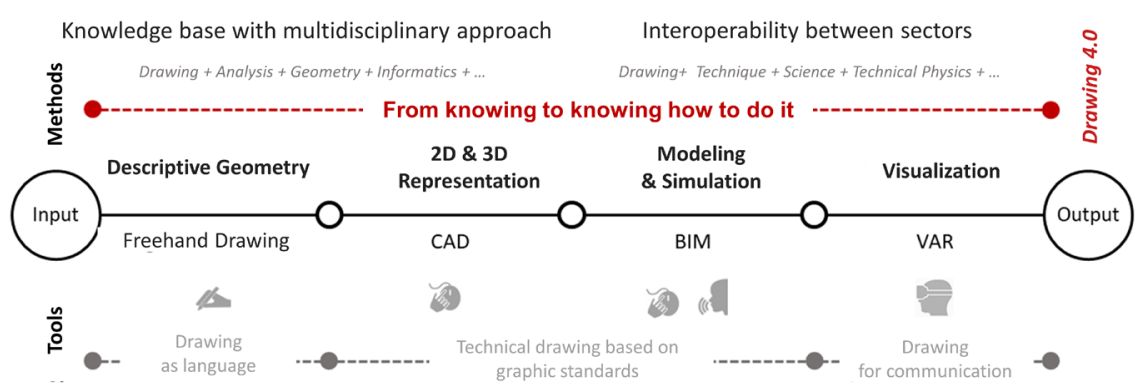


ments of Technical Design, mastery of tools, integration of knowledge). The methodological approach has foreseen a preliminary phase for the collection of requirements. The large number of commands present in the software interface makes it difficult to use interface methods alternative to standard manual controls by configuring, as the main difficulty in using technologies based on voice control, the fact that the graphical interface elements that characterize technical drawing software are missing. For this reason, it is necessary to create a replacement method for performing the available operations. Best practices for creating software that integrates voice assistants define in an operational sense how machine-user queries should be formulated [Alexa Skills Documentation 2020]. It is essential to follow semantic rules, in order to ensure simplicity in the formulated questions, including criteria of clarity (omission of adjectives and misleading terms that could undermine the understanding of the request) to obtain a dialogue model that can take into account the fact that the user does not have text or icons in front of him, but interacts and receives input through sound. The application theme of this technical exercise was the representative elegance of conical figures, since the simplicity of their geometric properties and the elegance of their engineering applications have always attracted the attention of scholars. Once the application theme had been selected, the preliminary engineering phase of the assistant's voice prompts began.

As shown in (fig. 3), the user interacts with the platform through voice input by dialoguing with the device. This one will store the information and transmit it through HTTP REST protocol to the Cloud Provider, which, thanks to artificial intelligence algorithms based on Natural Language Processing, will convert the information into system variables. The choice to perform the processing separately, using the cloud provider, derives from the fact that:

I) The algorithms based on Neural Networks require high computational power and may cause an overload on the local CPU.

2) Many voice assistants rely on a fully integrated Cloud environment with exposed APIs, with optimized transmission methods and minimized latency.

3) The data is managed directly by the Cloud Provider and thanks to the high security standards, voice data is stored in compliance with current privacy directives.

Processing uses the Language Processing engine Amazon Alexa, which offers a suite of advanced development tools [Rao 2017]. At the end of the processing on cloud will be transmitted to the user's PC a payload, necessary to create the 3D forms, in JSON format, using also in this case the HTTP communication protocol. Once the payload reaches the user's computer, thanks to a logic including the schematization of the information in a file, hereinafter referred to as 'controller', the necessary information is extracted.

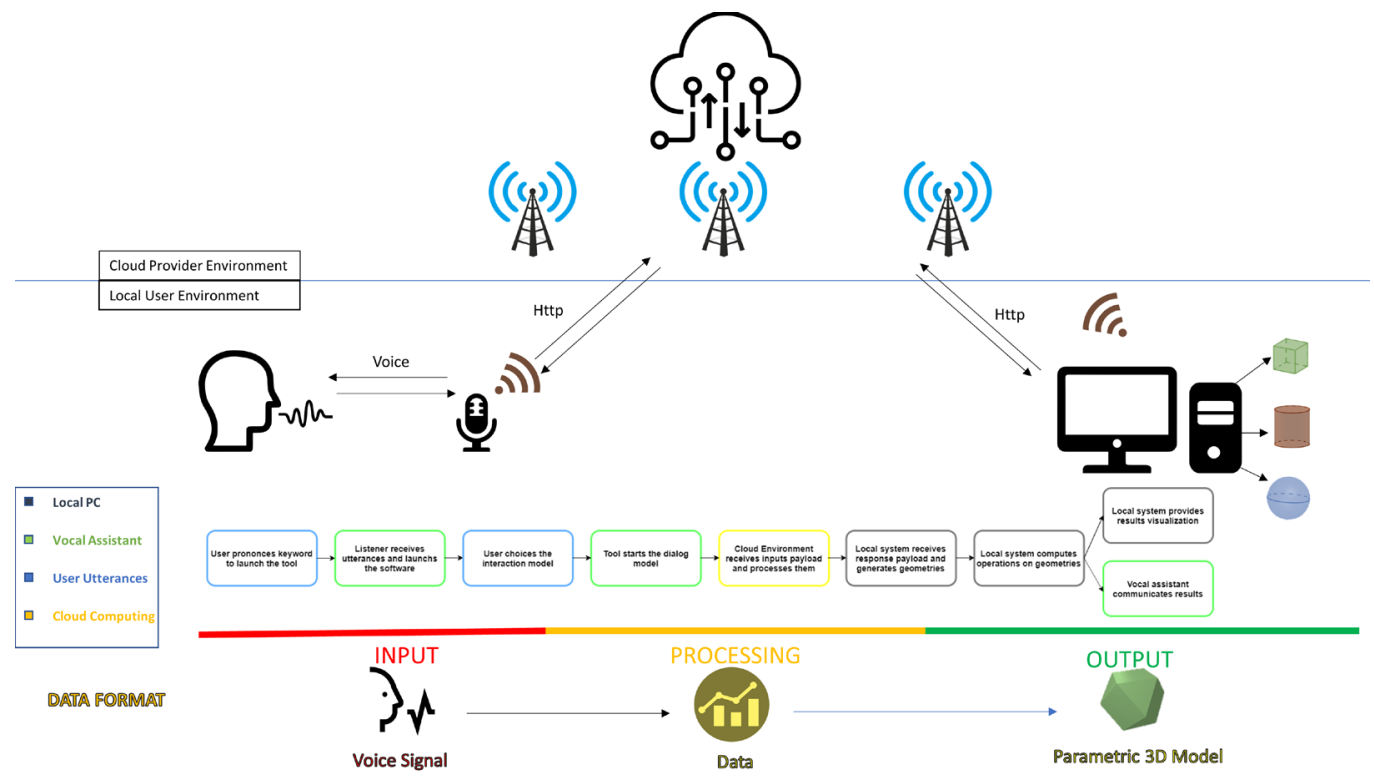


The functions of the script are:

I) Allow real time communication via HTTP protocol.

2) Convert and format the payload from JSON format to CSV format.

The information in the controller is transferred to the modeling software using the Dynamo visual programming plugin. The conversion from JSON to CSV is necessary for compatibility in reading Dynamo near real time information (fig. 4).

During the first phase, the controller is instantiated and the information is contextualized, creating variables within the technical drawing software. The data collection system inside the script is equipped with control functions that allow, in case of missing or incorrectly formulated data, the loading of default values defined in advance. The second phase of the algorithm allows the creation of geometric figures (double pitch/single and plane cone) starting from the previously loaded data. After creating the solids, Dynamo's logic will be used for the insertion of the operational blocks, necessary to perform the interaction between solids.

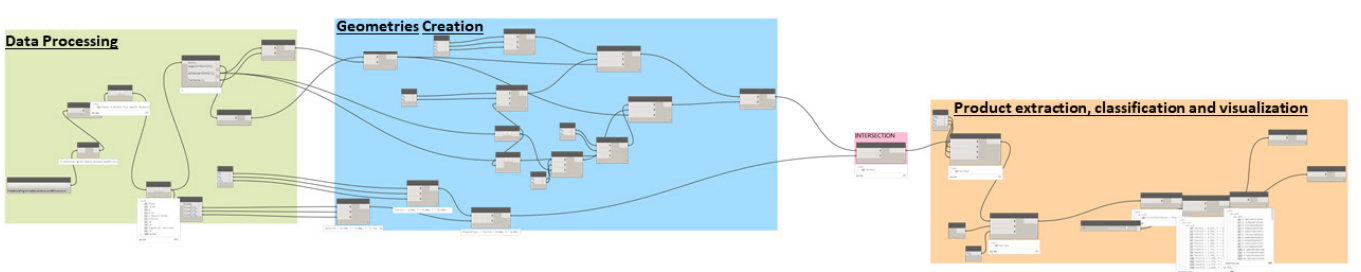

In the third block, the product is exported to a known position for display (fig. 5).

The algorithm is divided into two sub algorithms that differ from each other in the number of accepted inputs.

I. The Guided Procedure provides for the reception of cone and plane parameters. The variables include the positioning of the plane with respect to the vertical axis in terms of spatial coordinate and normal (inclination).

II. The Simplified Procedure involves creating the cone using the default variables preloaded within the script. The user will then communicate the inclination of the plane with respect to two axes. The positioning of the plane along the vertical coordinate will be initialized by default.

The junction point between the two flows is the classification and visualization of the product. In particular, the software, solving the general equation of conics, extracts the discriminatory parameters to determine the type of figure obtained.

The Guided Procedure has more control over high computational and time complexity than the simplified procedure. Focus is placed on the format in which these variables must be reported (fig. 6). If there is an error (for example the string obtained generates an error when converted to number), the system communicates that the value has not been correctly processed and asks the user to pronounce it again. Moreover, even if the data is correct, as far as numeric data is concerned, validity intervals have been set to avoid errors in the processing of the geometry. If the data does not pass the check, even in this case, the user will be asked again for the value indicating the anomaly.

\section{Conclusions}

The algorithm has been evaluated in terms of stability thanks to the contribution of 10 testers who tested the system out of box, without assistance from trained personnel and / or knowledge of the Dialog Model. In particular, the evaluation parameters were:

I) Effectiveness of interaction and verification of compliance with best practices.

2) Correct transmission of the data flow/correct production of the result. 

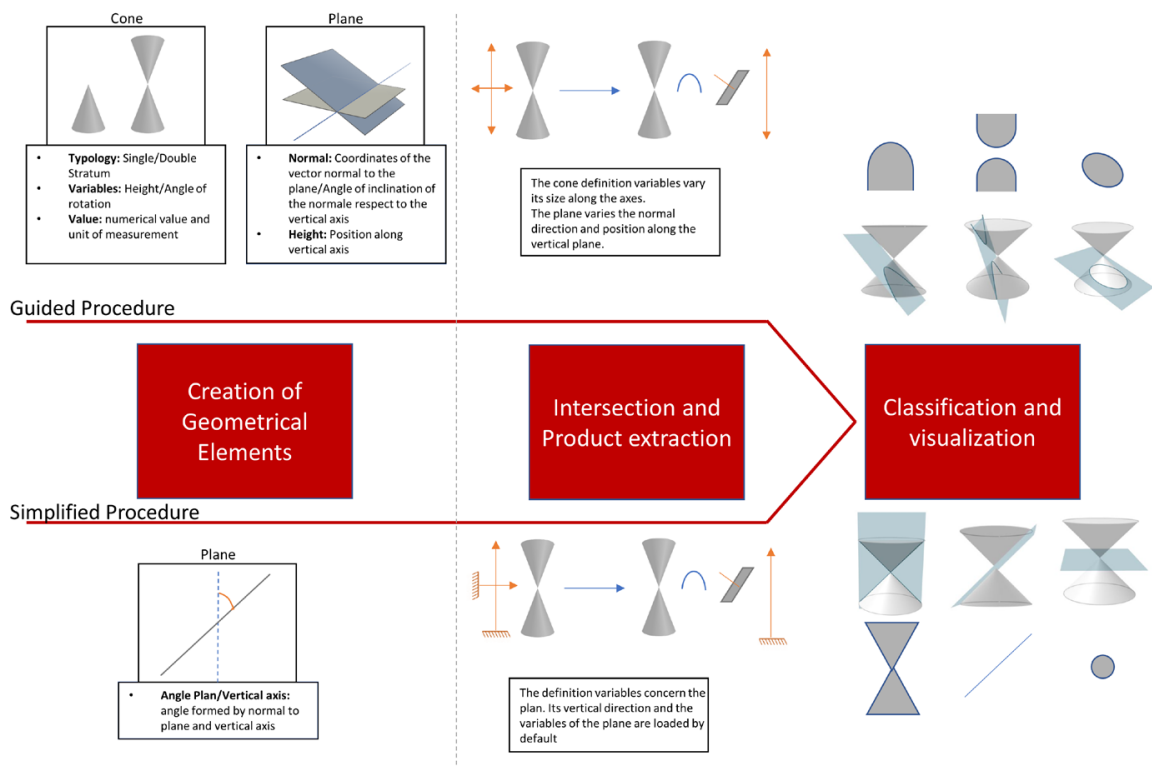

In the first case, thanks to the use of help functions that are called up when the tool is started and at the user's request, all the testers have successfully used the tool, arriving end to end to the result. In the second case, with the introduction of the control logic, possible semantic errors have been resolved. The system has shown excellent results in use. The transition to voice interfaces, which are certainly changing the needs of users (and not only of "millennials"), if properly developed, can be used even more in the engineering field to become also a support tools for users with reduced mobility of the limbs and unable to use the classic command interfaces.

Fig. 6. Infographic which lists the variables, grouped by procedure, that the user exchanges with the software.

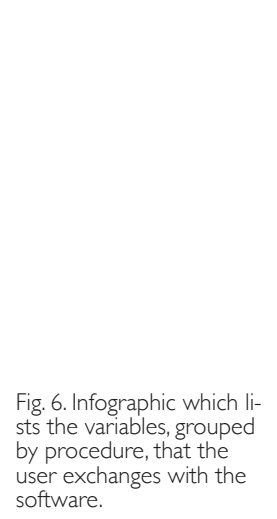

\begin{tabular}{|c|c|c|c|c|}
\hline & Variable Type & Prompt Question & [Type] Accepted Results & \\
\hline \multirow{5}{*}{$\frac{\frac{\mathscr{T}}{\pi}}{\square}$} & Tilt respect to vertical & $\begin{array}{l}\text { What is the angle of inclination of the } \\
\text { normal with respect to the vertical? }\end{array}$ & $\begin{array}{l}\text { [int]+[string] Dimension that defines the } \\
\text { angle value and its unit of measurement in } \\
\text { either degrees or radians }\end{array}$ & $\begin{array}{l}\text { Simplified } \\
\text { procedure }\end{array}$ \\
\hline & Normal coordinates & What are the coordinates of the normal? & [int] Integers triple & \\
\hline & Spatial position & $\begin{array}{l}\text { What are the coordinates of the origin of } \\
\text { the plane? }\end{array}$ & [int] Integers triple & \\
\hline & Typology & What kind of cone do you want to draw? & [string] «Single» or "Double Stratum» & \\
\hline & $1^{\circ}$ Variable & $\begin{array}{l}\text { What is the first variable needed to draw } \\
\text { the cone? }\end{array}$ & $\begin{array}{l}\text { [string] «Height", «Angle of rotation» or } \\
\text { "Generator» }\end{array}$ & \\
\hline \multirow{4}{*}{ 峁 } & $1^{\circ}$ Variable dimensions & What is the size of the first variable? & $\begin{array}{l}\text { [int]+[string] Numerical dimension with } \\
\text { associated unit of measurement }\end{array}$ & procedure \\
\hline & $2^{\circ}$ Variable & $\begin{array}{l}\text { What is the second variable needed to draw } \\
\text { the cone? }\end{array}$ & $\begin{array}{l}\text { [string] «Heights, «Angle of rotation» or } \\
\text { "Generator»! != } 1^{\circ} \text { variable }\end{array}$ & \\
\hline & $2^{\circ}$ variable dimensions & What is the size of the second variable? & $\begin{array}{l}\text { [int]+[[string] Numerical dimension with } \\
\text { associated unit of measurement }\end{array}$ & \\
\hline & Spatial position & $\begin{array}{l}\text { What are the coordinates of the cone's } \\
\text { origin? }\end{array}$ & [int] Integers triple & \\
\hline
\end{tabular}




\section{References}

Alexa Skills Documentation (2020). Tratto da: Amazon Developers: <https://developeramazon.com/it-IT/docs/alexa/customskills/voice-design-best-practices-legacy.html>:

Fiorentino Michele, de Amicis Raffaele, Monno Giuseppe (2002). Nuove tecniche di interazione per il Design: il CADVirtuale. In DDD INTERFACCE, Rivista trimestrale Disegno e Design Digitale, vol. 7, pp. I - 14.

Migliari Riccardo (2003). Geometria dei modelli. Rappresentazione grafica e informatica per l'architettura e per il design. Bologna: Edizioni Kappa.

Migliari Riccardo (2009). Geometria descrittiva. Milano: CittàStudi.

Osello Anna, Bocconcino Maurizio Marco (20 l0). Il disegno e l'ingegnere. Torino: Levrotto \& Bella.

Pascucci Cecilia (2000). Geometria descrittiva per il disegno industriale. Roma: Gangemi.

Rao Arun (2017). Comparing Amazon Alexa vs Google Home for Developers. Tratto da Medium: <https://medium.com/ voicelandia/comparing-amazon-alexa-vs-google-home-for-developers-cda37d9874c0>..

\section{Authors}

Anna Osello, Politecnico di Torino, anna.osello@polito.it

Francesco Alotto, Politecnico di Torino, francesco. alotto@polito.it

To cite this chapter: Osello Anna, Alotto Francesco (2020). Nuove frontiere per la didattica del Disegno. Il futuro è nei comandi vocali?/ New frontiers for the teaching of Technical Drawing. Is it possible to design with voice interfaces? In Arena A., Arena M., Brandolino R.G., Colistra D., Ginex G., Mediati D., Nucifora S., Raffa P. (a cura di). Connettere. Un disegno per annodare e tessere. Atti del $42^{\circ}$ Convegno Internazionale dei Docenti delle Discipline della Rappresentazione/Connecting. Drawing for weaving relationships. Proceedings of the 42th International Conference of Representation Disciplines Teachers. Milano: FrancoAngeli, pp. 704-717. 